\title{
MANAGEMENT OF ENERGY AND ENVIRONMENT CONSERVATION: CURRENT METHODICAL PROBLEMS
}

\author{
J. Michna \\ International Center for Energy and Environmental Policy, \\ 3 Wilhelmstrasse, Leimen, D-69181, GERMANY \\ J. Ekmanis, N. Zeltins, V. Zebergs \\ Institute of Physical Energetics, \\ 21 Aizkraukles Str., Riga, LV-1006, LATVIA \\ J. Siemianowicz \\ Silesian High School for Management \\ 2 Krasinskiego Str., Kotowice, 40952, POLAND
}

\begin{abstract}
The paper presents a continuation in the series of works devoted to the acute problems of energy use management in different periods of economic transition in the CEE countries. Research carried out by the team of scientists has resulted in creation of modern management methods. In particular, unitary indices were worked out which connect the consumption of energy carriers and environment pollutions in a definite time period and the values of production (services) realised in this period.

The cooperation of researchers from different countries has given rise to the ICEEP (International Center of Energy and Environment Policy), where under research are issues of the risk management in the conditions of informational uncertainty, non-knowledge, as well as dynamic and stochastic behaviour of systems (processes). The main emphasis in the methodical approaches is given to the complex (strategic) thinking, which would be necessary for establishment of global regulations in the scope of energy and environment conservation.
\end{abstract}

\section{INTRODUCTION}

Despite the great diversity of national economies, a thorough analysis reveals similar tendencies in their development (social aspect included). At the same time, it is obvious that the solution of problems stemming from the mentioned tendencies requires very different methodical approaches. Nowadays, of especial importance become such issues as progress of knowledge, choice of the most promising directions of scientific research, intensification of particular research, development of innovations, etc.; in full measure this is related to the sphere of energy and environment conservation. In this connection the following tendencies should be given primary attention:

1. General (though diversified) growth in the world population: minimal (even negative) population increase in the developed countries and great population increase in the economically poor countries.

2. Growth in the global market caused by the world's economic development, which necessitates involving complex systems' methods (e.g. complex 
thinking) and implementing the global principles for socially-economic development.

3. Acceleration of socially-economic changes (supported by competition), and increase in importance of strategic socially-economic analysis of stochastic, fuzzy, etc., phenomena in their dynamics.

4. Development of the information- and service-society and, therefore, the need for additional information and its reliability.

5. Uneven development of social prosperity in different countries of the world, especially as concerns the incomes in particular societies and professional groups; ambiguous evaluation of the work realised by different professional groups which are directly involved in the realisation of concrete products or services; competitiveness on the scale of a country and an enterprise; and educational level of each country and enterprise.

6. Limitations on the access to raw materials, especially to food, fuels and water.

7. Increase in the environmental pollutions, especially from dusts, emissions of waste gases $\left(\mathrm{SO}_{2}, \mathrm{NO}_{\mathrm{x}}, \mathrm{CO}_{2}\right.$, etc.), dirty water, and so on.

As a result, in the analysis of a particular system of necessity becomes to take into account: a greater number of appropriate parameters and connections; the difficulties of acquiring appropriate information (especially with a definite certainty degree); the general character of uncertainties and risk in sociallyeconomic problems existing in reality. Consequently, real systems met in the socially-economic praxis are described using oversimplified approach. Therefore it is necessary:

- to develop the methods for optimal simplification of complex systems, and

- to carry out the sensitivity analysis of the potential influence of appropriate parameters and connections on the characteristic sizes of a discussed system.

It is timely to change the obsolescent methods of thinking and concentrate more on the following:

1. Use of complex (on a system's scale, ecological, cybernetic, strategic) nonlinear thinking.

2. Consideration of parameters and connections (which could be not only deterministic but also of stochastic, fuzzy, etc. quality) in their dynamics.

3. Taking account of important external implications from: economic criminality; ever growing tendencies to use exaggerations when estimating real situations; non-knowledge; and the most influential concomitant phenomena.

It should be noted that in the past the development of knowledge was mainly oriented to the technically-scientific research, and the system thinking was ignored; in the economic praxis and in the applied science the linear thinking dominated.

Being useful in the past, such simplifications became a serious handicap to the development of knowledge and especially of complex thinking. Recently, the scope of using simplified thinking has noticeably decreased.

\section{METHODS FOR MANAGEMENT OF ENERGY AND ENVIRONMENT CONSERVATION}

The general situation described above has given rise to the predominant use, in the sphere of energy and environment conservation, of energy saving and 
environmental pollution values as the most important criteria. Therefore the primary attention should be given to the energy and environment saving activities those directed towards reducing the consumption in this sphere and determination of potential projects (having real chances for realisation) which would allow achievement of concrete energy carriers' saving and acceptable pollution level.

It is especially important to concentrate on the activities that improve the energy efficiency and, as a result, also environmental saving effects in the scope of processes existing on different management levels (i.e. definite technological operations, concrete technological processes at the level of an enterprise, a socially-economic organisation, etc.) in the major branches of economy (industry, building, municipal economy, transport, agriculture, etc.); touching the whole national economy, international organisations and the world economy.

In our research it was proposed to use the unitary indices for consumption of energy carriers and environment pollutions, defined as quotients of consumed energy carriers or emitted pollution in a definite time period, and the values of production or services realised in a definite time period.

However, in the economy practice such indices evaluated for different time periods are sometimes widely varying, since in reality different fluctuations in the energy and environment consumption occur whose character can be deterministic (e.g. operative organisational changes), probabilistic (e.g. probabilistic changes of workers' behaviour), stochastic (e.g. process fluctuations) and fuzzy (e.g. parameters which can only be defined by an ambiguous method).

With the mentioned obstacles taken into consideration, the research into the energy and environment conservation issue, especially as related to the (quasi)technological processes in which the consumed energy and environment can be described by "stochastic- stationary" functions, has developed using the ordered diagrams of the mentioned functions, which illustrate the repetition rate of a concrete parameter value in a defined time period and the density diagrams of concrete parameter variations from average in a defined time period.

The research carried out in this scope has stressed that the causes of the discussed variations in concrete parameters have not only probabilistic but also deterministic character, and therefore also the relevant diagrams for the ensuing time periods are to assume another form.

The background for such a situation lies in the processes (dynamic, stochastic, etc.) existing in concrete production and services; only in special cases the assumption is allowed that the discussed function has a stationary character (since only the so-called stationary-ergodistic functions have the quality that the probability of a concrete incident is equal to that of a timely arisen incident) and the difference in the production (service) values is the measure of precision at determination of the consumed energy and environmental pollution values. Therefore a probable dispersion zone should be determined for the discussed diagrams at different time moments. In other words, in the real praxis all determined values of consumed energy or environmental pollution are to be treated as those of uncertainty size. Such quality characterises not only the energy and environment consumption processes, but all other socially-economic phenomena. We are therefore dealing with a commonly accepted thesis - "one is certain that all is uncertain". This thesis means that it is impossible to liquidate uncertain pheno- 
mena completely, so we should learn how to cope with uncertainties of real life, and use the methods allowing simplification of complex systems commonly existing in reality.

\section{IMPLICATIONS OF COMPLEX THINKING}

Development of knowledge and especially experience acquired while studying real systems (processes) make it possible to initiate complex research (based, in particular, on opinions and judgements) into socially-economic problems. To the fore is now brought the so-called complex thinking. The current situation activates the creation of new promising methods for management of systems (processes), also in the sphere of energy and environment conservation, where most efficient realisation of complex thinking could be expected.

At the same time, extension of the scope of complex analyses and judgements as related to concrete socially-economic problems is connected with fundamental structural changes in the discussed problems, so of primary importance becomes the so-called system (process) thinking. Such thinking is based on consideration of the systems (processes) as certain elements within a discussed problem; their behaviour functions (in relation to changes in the parameters having influence on the structure of a discussed problem), as well as their internal and external (i.e. related to a system's surroundings) connections.

The use of complex thinking favours creation of more complicated models of definite systems (processes), also in the scope of energy and environment conservation. Such models allow achievement of better approach to diversified systems existing in reality.

This means that the number of parameters and connections in the relevant models is ever increasing, which would allow taking account of not only deterministic and probabilistic but also fuzzy sizes. In the late 70-ies of the past century a theory of fuzzy sets was created, which is intended for consideration of diverse qualities intrinsic to the real systems (processes).

Currently, a great number of algorithms exist for various model structures and concrete conditions, which is connected with increasing need for the information to be applied to concrete models; simultaneously, additional difficulties arise owing to the necessity to take into account also their uncertainty degrees.

All before mentioned problems in the scope of energy and environmental conservation have one common property: increase in importance of uncertainties, which means that models with reduced complexity should be created. In other words: there are needed new methodical approaches; namely, those allowing choices of appropriate parameters and connections (also as relates surroundings of a discussed problem) based on which a model structure could be shaped that would reflect best the quality of a real system (process).

Therefore, of primary importance have become opinions (judgements) about the newly-arisen uncertainties resulted from simplifications introduced at modelling a real system (process).

Special attention must be paid to comparisons with the research results for other models and to the methods helpful in evaluation of the relative weight of definite uncertainties in a discussed system (process).

Methodical approaches of the kind should be based on the sensitivity analysis of a real system (process) as the whole - that is, sensitivity of its charac- 
teristics to potential parameters and connections. In such an analysis it is necessary to take into consideration fluctuations of all chosen (for describing the characteristics of a discussed system) parameters and connections, as well as implications of newly introduced or previously ignored parameters and connections.

Also a greater attention - not only in this scope but in all complex thinking considerations - must be given to the implications of the so-called indirect phenomena resulting from a concrete production or service technology and local conditions (both internal and external). As most important for the energy conservation in a particular technological process are the environmental concomitants. To such effects belong all environmental pollutants that arise from different dusts; waste gases $\left(\mathrm{CO}_{2}, \mathrm{SO}_{2}, \mathrm{NO}_{\mathrm{x}}\right.$, etc.) from burning; noises; constant wastes and water heating. As we know, these environmental pollutants are detrimental to the life of our world; in view of vital importance of relations between the life systems and the environment as well as owing to the development of "ecological" scientific research it became usual to call such thinking "ecological".

From the methodical point of view, the bulk of attention should receive parameters and connections which cause great difficulties at their modelling and quantification, especially when we try to describe environment conservation processes (the relevant sizes are called: common volumetric, dynamic, stochastic, fuzzy, uncertain, and non-linear).

Recently, it is much discussed about the so-called greenhouse effect as a source of climate changes worldwide. A considerable proportion of this effect results from emitted $\mathrm{CO}_{2}$ gases arising from burning of primary energy carriers. Therefore of primary importance has become scientific research aimed at better quantification of the relations between the atmospheric temperature changes and the resultant (mainly negative) implications. Especially important in this scope is quantification of two sources of world climate change: the variations in solar activity and the greenhouse effect (see J. Barkans.: On the Global Climate Change).

Independently of the results of about mentioned scientific research, significance of energy conservation is undisputed; it even will rise in relation to that of other activities involved in technological processes.

\section{CONCEPTION OF THE RATIONAL ENERGY USE}

Analysis of the primary energy supply risks in several OECD countries gives an emphatic picture (see Fig. 1) of the actuality and importance of this problem.

This figure shows that, for example, in Germany the risk of primary energy supplies has increased notably since the late1970s, and has more than doubled between 1990 and 2007. In the international comparison, only Italy and Poland currently post a higher vulnerability index at the primary energy level. The situation is considerably better in the UK, France, Sweden and the US. The main reason for Germany's elevated supply risk is its growing dependence on imported energy and the associated rise in demand for imports from supply regions with high or growing geopolitical risks. Germany's impressive energy efficiency record and excellent energy infrastructure have done much to reduce its vulnerability at the end-user level. Still, supply risk at the end-user level did increase by around 18 percent between 1990 and 2007. To avoid further increases in the future, it is essential that investments be directed at ensuring the ongoing maintenance and expansion of these energy systems. 


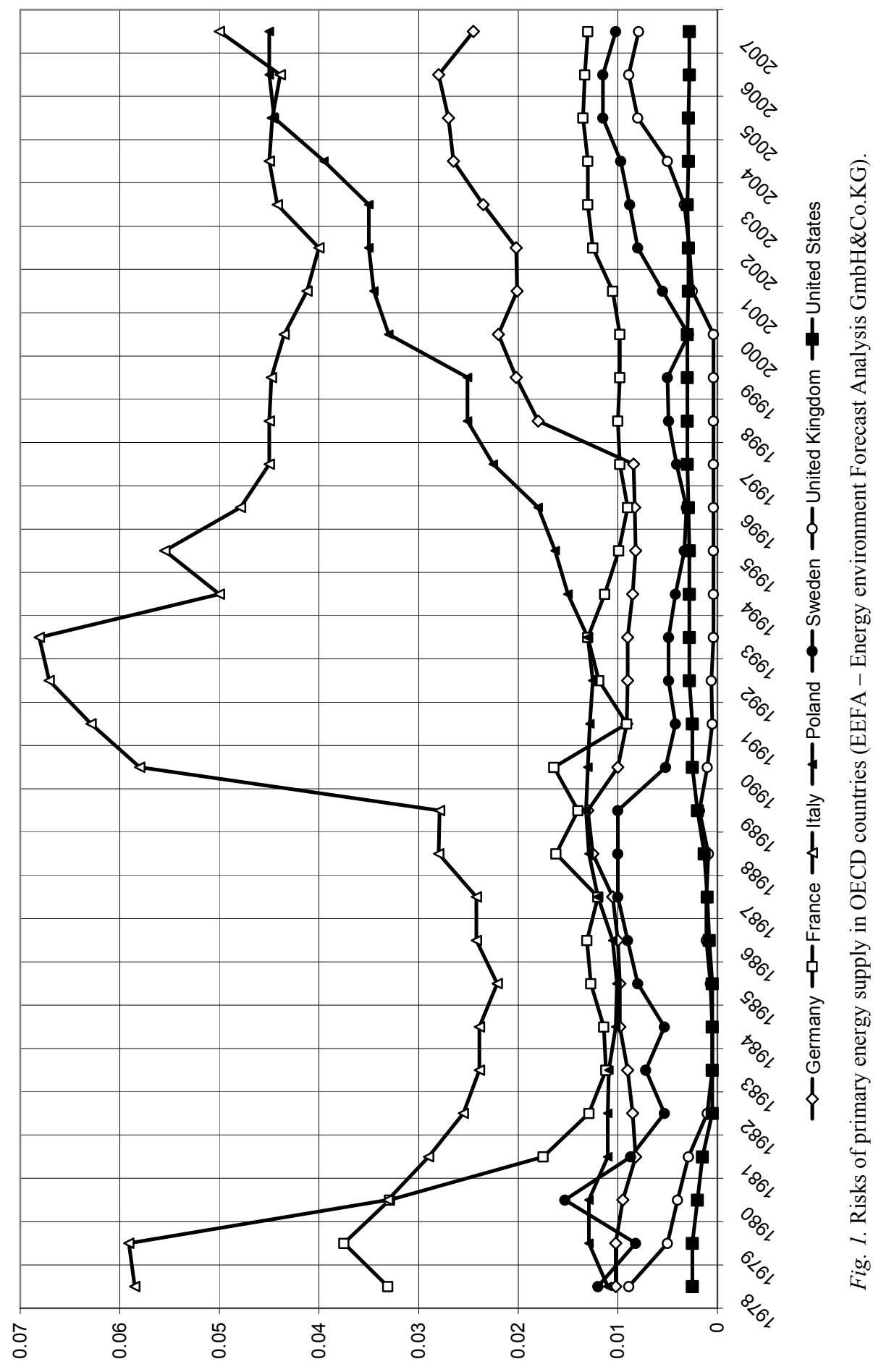


All socially-economic activities need energy; therefore it can be stressed that the use of energy is the imperative condition for them to be realized. As universal criteria for all activities of the kind the unitary indices of consumed energy can be used. The application of such universal criteria would be helpful since the measurements of energy consumption are relatively precise.

The universal character of the energy use has led to the situation when of importance become not only energy saving effects owing to concrete activities, but also other concomitant effects, especially technological (built in the quantitative and qualitative indices of definite products and services); transport of substances (solid and fluid materials, gases); climate heating/cooling, and so on.

As a result of complex thinking, already in the 70 s of the past century a conception of rational energy use (both in Central and Eastern Europe) was created.

According to this conception, the aim of rationalisation is achievement of a concrete effect with the minimum outlay, or, with a definite outlay to achieve the maximum effect; activities that meet these conditions are called optimal.

Recently, these basic conditions have been defined more precisely (J. Michna et al.): though all participants in the market competition try to use these conditions, the achieved effects can be very different, since both the internal and external conditions can have different influence on a discussed activity. Therefore it is advisable to use the criterion of success for a definite rational sociallyeconomic activity: to achieve better results from it than those achieved by potential competitors.

As concerns strategic thinking, it is ever increasing in importance; the aim of such thinking is more and more directed towards achieving success not only in a general but also in the strategic sense. When processes or enterprises possess such capacity they are considered as economy units with survival ability, in analogy with living systems (processes). Especially useful is such methodical approach in the organisation and realisation of activities which are characteristic of sustainable development.

Currently, steep changes in the structure and characteristics of definite systems (processes) are observed; mainly, they result from the already mentioned sharpening of competition as well as from technical, organisational, and management development. These tendencies have also stressed the significance of dynamic problems and appropriate methodical approaches, especially those helpful for identification of new uncertainties arisen in this scope. At the same time, this has, after all, caused additional difficulties at describing the characteristics of appropriate systems and processes. Especial stress must be given to the increased use of differential equations that are in principle non-linear, which earlier were simplified to linear ones in order to allow description of the so-called transient states of technological processes (the energy and environment conservation subprocesses included).

The large-scale computerisation has essentially simplified the past approaches, allowing at the same time more penetrating descriptions of phenomena observed in reality. This also made it possible to search among the so-called chaotic problems existing in the operation of the machines and facilities related to the energy production and environment conservation, which affect the decision 
making processes in this sphere. Increased interest in the real dynamic problems of energy and environment consumption processes has caused also interest in the socalled living systems (processes), especially as concerns possibilities to use the experience of such systems (processes) for efficient changes in the currently applied technical, organizational and management methods and facilities.

Of especial promise are methods related to the self-regulated (relatively independent) subsystems of the discussed technological systems; in this sphere efficient innovations could be expected. They have also enabled a higher level of strategic thinking as related to diverse aggregated socially-economic systems (processes), and particularly to those including energy and environmental subsystems (sub-processes). In other words, it could be stressed that nowadays a great scope exists for using the experience of natural systems and extending the methods of complex thinking for the phenomena of the whole Universe. Such thinking is called cybernetic. In the research carried out in this direction (J. Michna et al.) it has been found that employment of feedbacks similar to those of living systems allow essential structural simplification at description of appropriate processes. Increased interest in the dynamic phenomena observed in living systems (processes) has been realised in the idea to use their experience for development of people creativity, especially as concerns new ideas and innovations helpful for the efficiency increase of defined activities. In particular, scientific results borrowed from the neurology could be interesting for managers.

As a result of the above mentioned new methodical approaches a noticeable increase in significance is observed for the systems whose parameters and connections are varying in time. In this regard, of particular importance are aggregated systems - i.e. those including definite subsystems (based on appropriate technological operations or technological activities) and following in a time sequence, from begging to end, in other words: which are processes.

Another aspect of such systems (processes) to be stressed is that the opinions of clients have fundamental importance, both at the initial stage of realising a concrete process and after realisation of a concrete product or service. From the very beginning we must know: "what potential clients wish to acquire?" and, on the other hand: "is there assurance that the realised product or service will be accepted by potential clients?" Such formulation of the problem has recently given rise to the discipline called "Process management" (J. Michna et al.), especially focusing on the flexibility at meeting the wishes of potential clients. This problem has also contributed to the progress of general economical development and, therefore, also to speeding-up the technical, organizational, and management changes and the changes in the related methodical approaches. It also stressed the topicality of the "own"- that is, acquired through studies - knowledge. This, in turn, necessitates that appropriate postgraduate studies be organised as additional professional schooling methods - not only for workers, but also for managers.

Socially-economic globalisation, also in the above mentioned scope, has caused a request for global information about the opinions of potential clients in relation to concrete processes (enterprises) and definite products or services. As a result, noticeable is the development of useful methods efficient in this scope. Of especial significance has become research into organisation of the systems (processes) having certain autonomy for realisation of concrete aims derived from the information on the opinions of potential clients. 
Such strong general orientation towards clients has also contributed to essential increase in significance of the process management, and, as a result, to the creation of so-called process orientation. The orientation to clients needs complex and multidiscipline methodical approaches and has already been used for solving particular energy and environment conservation problems.

Already at the beginning of 70-s of the past century, when - both in the socially-economic praxis and in the appropriate scientific research - applications of the system theory increased to a noticeable extent, the rationalisation of energy consumption and, later on, rationalisation of environment conservation and the system thinking reached practical maturity.

In that time an innovation of three management levels (based on logical thinking) was introduced: operative, strategic and normative (regulative) (J. Michna et al.).

As the background, specific methods were developed for the research into the mentioned 3-level management, giving emphasis on the appropriate complex management in the energy and environmental conservation scope.

Since the management of the kind is to become a common practice in every socially-economic organisation, it is useful to analyse all potential energy and environment conservation activities on different aggregation levels - beginning with a technological process and ending with the whole industry as the association of municipal, agricultural, transport, and building sectors of the national economy in each country. In the analysis, the energy and environment conservation potential is to be defined for different aggregation levels, and especially for appropriate managers.

\section{RISK MANAGEMENT IN THE SCOPE OF ENERGY USE}

In all mentioned methodical problems it is possible to notice negative potential implications from the uncertainty sources.

The results of scientific research carried out at the present time as well as analysis of the experience in this scope allow for the conclusion that - almost in all socially-economic problems - expansion of the relevant models indeed is helpful for making better diagnosis of a discussed problem, but, at the same time, it creates new sources of uncertainties which result from various uncertainties from the accessible information needed for appropriate calculations, methodical simplifications and non-knowledge. Therefore, of fundamental importance, in view of possible implications, are the effects of these uncertainties, and especially the probability of deviations from the planned effect of a definite activity (project) i.e. risk.

In the present situation, when implications from the global financial crises still exist, one necessity must be pointed out: in every socially-economic activity it is advisable (even mandatory) to carry out risk analyses. Therefore, in the official reports on the causes of existing world crises the wrong risk management (especially in the banking sphere) is indicated as most influential.

From the extent of arising losses it is evident that new principles of the WB system's regulation are needed to avoid similar crises in the future, and the instrument for this purpose is to become the appropriate risk management.

Helpful in the intensive development of the relevant risk management methods could be the results of research in this scope - e.g. carried out at the 
International Centre of Energy and Environment Policy in Central and Eastern Europe countries (ICEEP).

The ICEEP was initially organised for scientific research of the transformation problems in Central and Eastern Europe countries, and especially for identifying the uncertainties stemmed from the so-called post-transformation conditions in these countries (J. Michna et al.). Currently, a general basic scope has been configured for appropriate scientific research into more efficient risk management, to which belong activities allowing early warning (before a risk source arises); identification of risk sources; evaluation of risk sources; risk steering and risk control connected with steering corrections. In the scope of energy and environment conservation, realisation of risk management was initially based on analysis of:

- dispersions in the values of achieved parameters and connections, using appropriate models of definite energy and environment consumption processes;

- dispersions in the appropriate unitary parameters (connections) of similar processes (in the own country, in foreign countries);

- the own experience in managing the existing energy and environment consumption processes.

Therefore, different methods were worked out which were basically helpful for particular conditions only and required very dissimilar approaches. As a result, the use of excessive simplifications and stiff approaches in the discussed scope can be observed

In this connection it should be stressed that nowadays the praxis of exaggeration (both in a positive and in a negative sense) has become a common phenomenon and a cause of newly arising uncertainties and risk sources. The described situation calls for the use of complex thinking, putting in the forefront such notions as confidence (in all cooperation activities) and a good reputation.

The appropriate risk management should be based on a very penetrating analysis of a definite system (process), with consideration of all potential disturbances, fluctuations and technical, organisational and management changes. Only such a basic approach would allow simplifications (made using before the mentioned methods of sensitivity analysis) concerning the factors having influence on the behaviour of a definite system (process). Advantages of such an approach consist not only in the possibility to reveal negative phenomena, but also in the arising possibility to derive the potential of positive phenomena from commonly existing uncertainties. This means that we would be able to use such a "potential of chances" for development of a discussed system (process).

Therefore we can call the risk management also the "chances' management".

\section{CONCLUSIONS}

The described methodical problems of the energy and environment use are in an important development phase, since the incessant financial world crisis is a clear illustration of negative consequences of ignoring them. In a drastic form noticeable are the negative results of the lack of common complex thinking as applied to the socially-economic development. In this phase it is necessary: 
- to pose obstacles against the existing tendency for excessive simplifications of real systems (processes);

- in every situation to assess admissibility of the used simplifications;

- to recognise commonly existing uncertainties;

- to arouse opposition against commonly existing exaggerated kinds of opinions (both positive and negative);

- to develop activities against the economic criminality and too great diversification of the life levels in the world.

As concerns the activities in the energy and environment conservation, at the ICPP appropriate research will be organised aiming at the efficiency improvement of presented methodical problems, giving particular attention to the management efficiency in this scope.

Based on the results of previous research works carried out at the ICEEP, its further investigations and activities will be concentrated on the three basic directions:

- general tendencies in economic development and the related modern management methods that can be adapted to local conditions;

- replacement of specific local management conditions in compliance with modern tendencies in this scope;

- creation of new - more efficient - risk management methods necessary for safeguarding the survival ability of appropriate processes (enterprises).

As follows from the current state of the energy and environment conservation activities in CEE countries, great dispersions in the evaluation of commonly used appropriate parameters and connections - both in a concrete system (process) and its surroundings - could be expected; therefore, very useful will be research and analysis of similar systems (processes) - especially concerning the causes of such dispersions, because they are also risk sources.

Of particular value will become efficient risk management methods in the international organisations dealing with innovations, which implies dynamic and sometimes chaotic behaviour of systems (processes) under the conditions of nonknowledge, involvement of the notions borrowed from other spheres (e.g. game theory), etc.. In this cooperation, probable policy of potential competitors should be considered, with the confidence between cooperation partners being brought to the fore.

From the above it follows that global regulations should be worked out with the aim of avoiding the creation of financial crises similar to currently existing ones. Of especial importance for the discussed scope will be establishment of global duties on providing the appropriate risk management; decreasing the differences between real and virtual values; and decreasing the differences in the employee incomes.

\section{REFERENCES}

1. Michna, J. et al. (1982). Prognoza energetyczna Polska 2020. (Warszawa).

2. Michna, J. (1987). Energy conservation policy. UNDP/UNIDO I (Vienna).

3. Michna, J. (1994). Energy conservation policy. UNDP/UNIDO II (Vienna).

4. Michna, J. (1994). Energy conservation policy during the transition period. UNDP/UNIDO IJ GEI (London). 
5. Michna, J. \& Krawczynski, A. (1996). External impediments to the formulation of economic and energy policies. London: IJ GEI.

6. Canter, L.W. (1996). Environmental impact assessment. (USA).

7. Carter, J., \& Michna, J. (1996). Energy conservation policy: applying market principles to former centrally planned economies. OPEC (Vienna).

8. Krawczynski, F., \& Michna, J. (1996). External impediments to the formulation of economic and energy policies by transition countries. London: IJ GEI.

9. Manning, J. (1996). The coming energy revolution. Avery Publishing.

10. Ney, R., \& Michna, J. (1996). Implikacje zasad zrownowazonego rozwoju na polityke energetyczna i srodowiskowa panstw w okresie transformacji. Warszawa: Nauka.

11. Michna, J., Miskinis, V., \& Zeltins, N. (1997). Implications of transition period conditions on energy policy in Baltic countries being in transition, Energy Strategies in the Baltic States: From Support to Business (WEC Baltic Regional Forum, Riga, LATVIA) Vol. I

12. Käär, H., Michna, J., Miskinis, V.\& Zeltins, N. (1997). Actual energy efficiency problems in Baltic Sea countries being in transition, Energy Strategies in the Baltic States: From Support to Business (WEC Baltic Regional Forum, Riga, LATVIA) Vol. II.

13. Krawczynski, F., \& Michna, J. (1997). Effektivität Westlicher Hilfe im Energiesektor. Energiewirtschaftliche Tagesfragen (Essen).

14. Kapala, J., Michna, J., Ekmanis, Yu., \& Zeltins, N. (1998). Research- based ecological concept of energy management for the Baltic States in transition period, Latv. J. Phys. Tec. Sci., (5), 3-13.

15. Goszcz, A., \& Michna, J. (1998). Problems of Liberalisation in the energy sectors of transition countries. London: IJ GEI.

16. Ekmanis, J., Zeltins, N., Kapała, J., \& Michna, J. (1999). Methodical problems on energy conservation policy in central and Eastern Europe Countries. World Energy Council, Regional Forum "Central and East European Energy Policies, Markets and Technologies for $21^{\text {st }}$ Century” Vilnius (Lithuania).

17. Kapała, J., Kaleta, P., Michna, J. \& Zeltins, N. (1999). Metody programowania racjonalizacij użytkowania energii, Instytut podstaw inżynierii, Środowiska PAN: Część I-37 storon.

18. Kapała, J., Kaleta, P., Michna, J. \& Zeltins, N. (1999). Metody programowania racjonalizacij użytkowania energii , Instytut podstaw inżynierii, Środowiska PAN: Część II-40 storon, 2 załączniki.

19. Michna, J., Kaleta, P., Kapała, J., Maksymowicz, R., Mantorski, Z., Miskinis, V. \& Zeltins, N.(1999). Matematyczane modelowanie procesów racjonalizacji użytkowania energii, PAN IPIŚ PRUE ZESZYT (1).

20. Capelhat, B., \& Turner Kennedy, W. (2000). Guide to energy management. Fairmont Press.

21. Convery, F. (2000). A guide to policies for energy conservation. EE London.

22. WEC (2000). Energy for tomorrow. London.

23. Kapala, J., Michna, J., Ekmanis, Y. \& Zeltins, N. (2001). Still transition or a new situation in energy conservation policy in Central and Eastern European countries? Intern. J. Glob. En. Issues, Energy conservation policy in Central and Eastern European countries, UNESCO, 16, (1/2/3).

24. Ekmanis, J., Frormann, D., Kapala, J, Michna, J., \& Zeltins, N. (2001). Analysis of energy and environment policy in the CEE countries: from the preparatory phase to post-transition. Latv. J. Phys. Tech. Sci., (5), 3-13.

25. Michna, J., Frormann, D., Bartoš, J., Gnedoy, M., Kaleta, P., Kapała, J., Krawczyński, F., Mészáros, G., Miškinis, V., Rousek, J., Rouytcheva, M., Rudi, Ü., Ruginá, V., 
Viksna, I., \& Zeltiňš, N. (2001). Energy conservation policy. Polish Academy of Sciences, Institute of Environmental Engineering, (1) 226 p. (in English, German and Russian).

26. Michna, J., Kapala, J., Ekmanis, Yu., Frormann, D., Zeltins, N., \& Kaleta, P. (2001). International Centre for Energy and Environmental Policy (ICEEP) for Central and Eastern Europe Countries, Polish Academy of sciences, Institute of environmental engineering. Zabrze, Düsseldorf, Riga. "Energy conservation policy” Zeszyt Specjalny: 28 p. (in English, German and Russian).

27. WEC (2001). Sustainability from energy perspective. London

28. Michna, J., Frormann, D., Zeltins, N. \& Kaleta, P. (2002). Present and future energy and environmental policy problems in Central and Eastern European countries. International centre for energy and environmental policy, Bulletin 1.

29. Michna, J. (2003). Zarzadzanie produkcja. Katowice: SWSZ.

30. Schwister, K. (2003). Umwelttechnik. Leipzig: Fachbuchverlag.

31. Wesseler, J. (2003). Risk and uncertainty in environment and natural resource economics. EE London, USA.

32. Sornette, D. (2004). Critical phenomena in natural science. Springer.

33. Ekmanis, Yu., Michna, J., Stania, A., \& Zeltins, N. (2004). Uncertainty in energy conservation policy. Foundation for Energy and Environmental Policy, 6 Wolności , 41-700 Ruda Śląska, Poland, ISSN 0867-2172, ZESZYT NR 4/2004

34. Michna, J., Stania, A., Kalka, M., Zeltins, N. et al. (2005). Main risk sources identification on energy conservation policy in CEE countries. International centre for energy and environmental policy, Energy conservation policy, Poland, Zeszyt (issue) 1.

35. Mandelbrot, B. (2005). The misbehaviour of markets. Basic books. New York.

36. Meier, P. \& Munasinghe, M. (2005). Sustainable development in developing countries. EE: Cheltenham (UK), Northampton (USA).

37. Black, J., Lodge, M., \& Thatcher, M. (2005). Regulatory innovation. EE: Cheltenham, (UK), Northampton (USA).

38. Praag, C.M (2005). Successful Entrepreneurship. EE: Cheltenham (UK), Northampton (USA).

39. Frormann, D., Michna, J., Stania, A., Ekmanis, J., Zebergs, V., \& Zeltins, N. (2006). Present risk management problems on energy and environmental policy in central and Eastern Europe countries. Latv. J. Phys. Tech. Sci., (3), 41-51.

40. Frormann, D., Michna, J., Stania, A., Ekmanis, J., Zebergs, V., \& Zeltins, N. (2006). Present-day problems of energy conservation policy in Central and Eeast-European countries, Latv. J. Phys. Tech. Sci., (5), 68-74.

41. Müller, C.F. (2006). Rationelle und Regenerative Energienutzung. Heidelberg.

42. Sinn, H.W. (2006). Das Grüne Paradoxon//Econ. Munich.

43. Zhong, I. (2006). Integration of fuzzy logic and chaos theory. Berlin: Springer.

44. Frormann, D. (2007). 15 Jahre Zusammenarbeit der Ema mit Zentral und Osteuropäischen Ländern, Düsseldorf.

45. Mulder, P. (2007). The economics of technology diffusion and energy efficiency. EE: Cheltenham (UK), Northampton (USA).

46. Michna, J.(2007). Zarzadzanie Ryzykiem Produkcji. Katowice: SWSZ.

47. Ney, R., Michna, J., Ekmanis, Yu., Zeltins, N., \& Zebergs, V. (2008).Energy use and related risk management problems in CEE countries. Latv. J. Phys. Tech. Sci., 45 (1), 41-51.

48. Ney, R., Ekmanis, Yu., Michna, J., Zeltins, N., \& Zebergs, V. (2008). The reputation risk management. Latv. J. Phys. Tech. Sci., 45 (5), 48-59.

49. Berninger, C. (2009). Management von Reputationsrisiken in Banken. Akademische Schriftreihe. 
50. Kühlmann, T., \& Haas, H. (2009). Internationales Risikomanagement. Oldenburg.

51. Szymanek, D. (2009). Organisatorische Risiken in Geschäfsprozessen. Ver. Müller.

52. Michna, J. et al. (2010). Risk valuation on energy and environment conservation in CEE countries. London: IJ GEI (special issue).

53. Michna, J. et al. (2010). Zarzadzanie ryzykiem racjonalnego uzytkownia energii $w$ krajach Centralnej $i$ Wschodniej Europy. Katowice: SWSZ.

54. Ekmanis, Yu., Zebergs, V., Zeltins, N., \& Davis, A. (2010). Risk-reducing problems of the Latvian gas supply. Int. J. Global Energy Issues, 34 (1/2/3/4), Interscience Enterprises Ltd. (London): 78-90.

55. Barkans, J., \& Zalostiba, D. (2010). On the global climate change. (Preface: N. Zeltins, Latvian Member Committee/WEC). Riga: RTU Publishing House. http://85.254.195.140/images/stories/arhivs/2010/Barkans2.pdf

\section{ENERĢIJAS UN VIDES SAGLABĀŠANAS MODERNU VADĪBAS METOŽU PROBLĒMAS}

I. Michna, J. Ekmanis, N. Zeltiňš, V. Zēbergs, J. Siemanovičs

\section{Kopsavilkums}

Enerǵijas un vides saglabāšanas problēmas tiek plaši pētītas un ir izstrādātas modernas menedžmenta metodes. Ir izstrādāti unitāri indeksi laika periodam T un produkcija šin̄̄ periodā. Praktiski jārēḳinās ar informācijas varbūtību, neskaidrību, stohastisku utt. Pētījumu attīstība rāda nepieciešamību iesaistît pêtījumos komplekso domāšanu (komplekso pētniecību), tas saistīts ar jaunu enerǵijas un vides saglabāšanas vadības metožu veidošanu. Attīstoties pētījumu metodēm, rodas arī jaunas informācijas nenoteiktības un risinājumu riski. Risku vadības menedžmenta pētījumus paredzēts veikt Centrālās un Austrumu Eiropas valstu Starptautiskā Energijjas un ekologijas politikas centrā (International Center of Energy and Environment Policy in Central and Eastern Europe countries - ICEEP) un citos vadošos pētniecības centros, attīstot kā jaunu svarīgu pētniecības virzienu. 